\title{
Inclusion of Indigenous Knowledge System (IKS) - A Precondition for Sustainable Development and an Integral Part of Environmental Studies
}

\author{
Ellen Carm* \\ Oslo and Akershus University College for Applied Sciences \\ Oslo, Norway
}

\begin{abstract}
UNESCO (2005) launched the Decade of Education for Sustainable Development, 2005-2014, and as we now proceed into the final year of that decade there is a time for asking whose development? That question heavily relies upon what type of education, which again leads to aspects concerning epistemological lenses. I am using my experiences and research from two totally different assignments; an evaluation of a post-literacy and skills program in rural Laos, and the other aimed at developing and implementing a localized approach to HIV/AIDS education in Zambia. The outcomes from the two interventions revealed that in order to initiate and sustain change and development, it was crucial to ensure the inclusion and merger of multiple knowledge systems, science and traditional knowledge. That requires a focus on how. In other words, the processes we put in place to ensure the recognition and merger of different epistemologies are crucial to ensure sustained local development.

The paper briefly discusses key concepts related to multiple knowledge systems, education for sustainable development, and different conceptualization of learning and teaching methods, and explores how environmental education can contribute to sustainable development. The last section illustrates how expansive learning can be applied as a method and a tool to analyze the processes at stake, and outcomes of participatory and inclusive interventions. The paper elaborates on the methodology and shows how a multi-voiced approach can bridge the gap between different epistemologies, e.g. Indigenous Knowledge and Western Knowledge, create space for interaction and negotiations among a diverse group of stakeholders and actors to reach to the local innovations and development activities.
\end{abstract}

Keywords: Situated learning, indigenous knowledge, inclusion, sustainable development, expansive learning

\section{Introduction}

As an external partner in a master program on Environmental Education and Sustainable Development at Kathmandu University, and having an educational and developmental background, I was challenged to explore how pedagogy and learning theory can contribute to visioning a broader understanding of environmental studies through a cross-disciplinary approach. 


\section{Established and Situated Conceptualizations of Learning}

Learning processes have traditionally been characterized as vertical or linear input oriented models of learning. There is a competent "teacher" who knows what is to be learned, according to a fixed content. It is a self-evident presupposition that the knowledge or skill to be acquired is itself stable and reasonably well defined. Learning processes are usually viewed as processes where a subject (traditionally an individual, more recently possibly also an organization) acquires some identifiable knowledge or skills in such a way that a corresponding change in the behavior of the subject may be observed (Engeström, 2008).

Much of the most intriguing kinds of learning in work organizations violate this as people and organizations are all the time learning something that is not stable, not even defined or understood ahead of time. Important transformations even from our personal lives as well as organizational practices originate from new forms of activity/ies which are not yet there. We literally learn while they are being created. Thus, there is no competent teacher. The conclusion then is that standard learning theories have little to offer if one wants to understand these processes (Engeström, 2001, pp.137-138).

A situated or contextualized perspective on knowledge regards knowledge as constructed through interaction with the environment, in a dialogue with others, through horizontal interaction and reflection (Du-Plessis, 2010). It is contextualized within a given culture and language, and knowledge is created through a process where new information is interacting with prior knowledge and experiences of the learner (Table 1).

Table 1

Conceptualization of Traditional/Established Versus Situated /Contextual Knowledge

\begin{tabular}{lll}
\hline Conceptualization & \multicolumn{1}{c}{ Traditional/Established } & \multicolumn{1}{c}{ Situated/Contextual } \\
\hline Learning & Cognitive - passive - & Embedded in community and \\
& selective & identity \\
Forms of knowledge & Canonical, theoretical, & Embodied/context-sensitive, \\
& codified, distilled in text and & indigenous \\
& manuals & \\
Understanding developed & Abstract/Universal & Transformation of identity \\
\multicolumn{1}{c}{ Transmission } & Vertical instruction by & Horizontal, collaboration \\
& authorities & with peers \\
\hline
\end{tabular}

(Adapted from Du-Plessis, 2010)

Traditional or established knowledge is cognitive, theoretical, codified according to certain rules, and tends to be abstract as opposed to situated and context-sensitive knowledge which is embedded in the local community, and a part of the people`s identity construction. Knowledge aiming at individual or local change and transformation is situated or 
contextualized, often termed indigenous as opposed to knowledge transmitted by authorities, viewed as universal. Along the following sections, the situated or contextual knowledge (also termed indigenous knowledge) will be further discussed.

\section{Indigenous Knowledge}

Indigenous knowledge is the knowledge that people in a given community have developed over time, and that continues to develop. It is based on experience, often tested over centuries of use, adapted to local culture and environment, dynamic and changing(International Institute of Rural Reconstruction(IIRR),1996).Even though Indigenous Knowledges are multiple we can still identify some common threads that bind them together (Breidlid, 2013). Indigenous Knowledges are by definition interdisciplinary, where local people think of and manage their natural environment as a whole system, developed in specific historical and cultural contexts, and are therefore "typically not generated but a set of pre-specified procedures or rules and orally passed down from one generation to the next” (Semali \& Kincheloe, 1999, p. 40, as cited in Breidlid, 2013, p. 31). Indigenous Knowledges bridge the spiritual world with the physical world, and it is therefore a need for assessing the extent to which the cultural embeddedness of knowledge creates meaning without becoming unacceptably distorted (Sillitoe, 1998).

Contextual realities, people`s everyday lives, micro- or meso-level activities guided by culture, and contextual or established knowledges can be explored, discussed and contested. If people are invited to take part in processes in order to identify and reflect upon what one just regards as "given", the traditions representing the rules and the division of labor, or any other activity we inherit from our ancestors, these processes may open up for localized initiatives and sustained developmental activities, based upon IKS..

Indigenous knowledge is situated and context specific but has the potential to be applied to other regions, being transferable and having time-tested reliability. This can be illustrated by studying the diagram made by villagers showing how livestock and land are owned by various castes in a Nepalese community. 


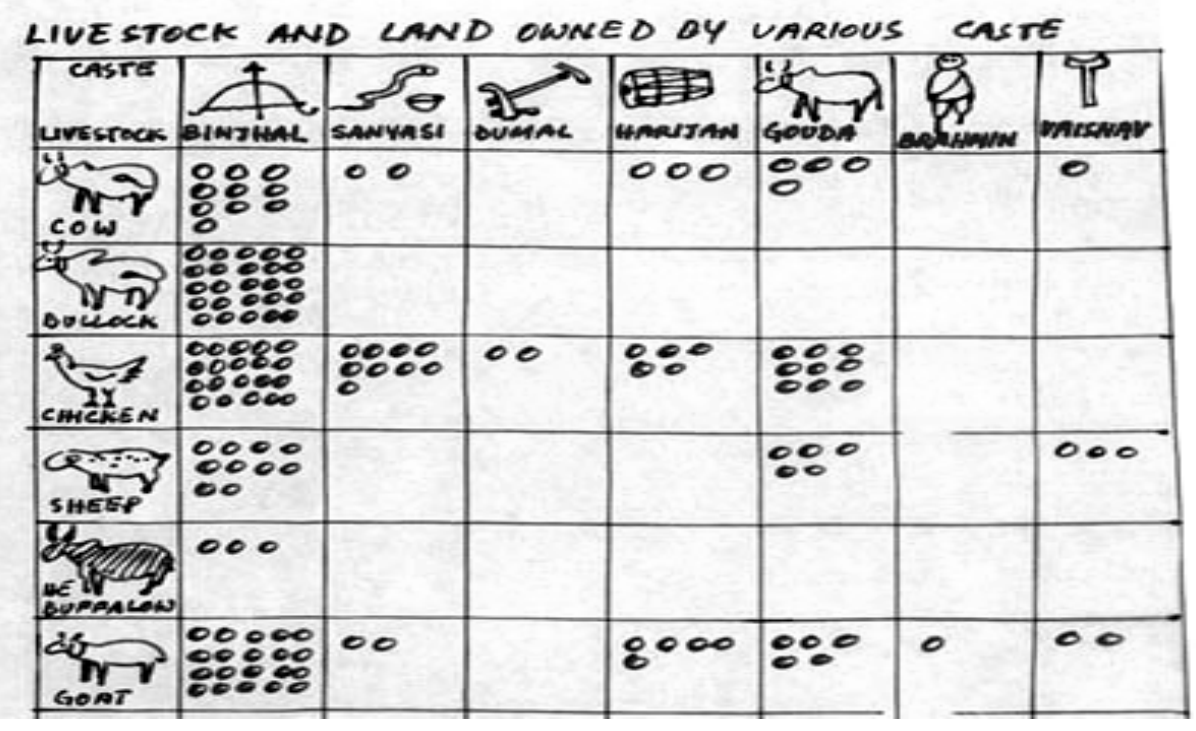

Figure 1.Use of matrix as a tool for identifying local context (Archer \&Cottingham, 1996).

As illustrated above, the livestock are unequally distributed among the different castes present in the diagram. This knowledge has been extracted from participatory learning activities among illiterate villagers, but presented in a table like this, the pattern of unequal distribution of wealth, may be applicable to communities populated by the same castes. Illustrations produced through participatory learning activities (PLA), allowing a diverse group of stakeholders to contribute, are useful tools, or instruments for reflections upon existing practices, for learning and conscientization (Chambers, 2004; Freire, 1970). The participants develop their own learning through interaction and dialogue, while at the same time constructing new knowledge, which may again open up possibilities for new solutions to local challenges (Engeström, 2001).

\section{Participation and Community Involvement}

Participation and community involvement has for the last two decades been a commonly agreed principle guiding development work in general, but the concepts rarely go beyond aid rhetoric and seldom reach down to grassroots level (Fortier,1993; Shaffer,1994;

Chambers,1997; Chambers \& Pettit, 2004; World Bank, 2005;World Bank et. al, 2009; Benjaminsen \& Svarstad,2010). Experiences from recent global reviews on success stories on improved and sustained agricultural developments and efficient food production unfortunately still argue the same. There is now an urgent need to move from rhetoric to implementation, a paradigm shift is still required (Benjaminsen \& Svarstad, 2010).

Building upon Arnsteins`(1967) ladder of community participation where she explores how involvement may be distorted and even be turned into manipulation, several applications of this theory have been developed. She argues that:

... the fundamental point [is] that participation without redistribution of power is an empty and frustrating process for the powerless. It allows the power holders to claim that all 
sides were considered, but makes it possible for only some of those sides to benefit. It maintains the status quo. (Arnstein, 1967)

The starkness of Arnsteins `(1967) framing of citizen participation, as an overt struggle for power between government officials and community activists being played out in settings varying from community halls to committee rooms, has been a touchstone for policy makers and activists for 35 years (Bruns, 2003). The only measure of participation according to Arnstein (1967) is the redistribution of power to make decisions and seizing this control as the true aim of citizen engagement. The different steps on her ladder relate directly to the degree to which citizens have attained decision making power with complete citizen control being defined as the highest step (Table 2). When moving from the lower rungs of Manipulation and Therapy through Informing, Consultation, and Placation, it is only the top three steps, Partnership, Delegated Power, and Citizen Control that demonstrate citizen power. The lower rungs are differentiated by the limitations of citizen power and its replacement with participation that does not necessarily influence decision-making (Arnstein, 1967).

Table 2

Ladder of Participation

8: Citizen control - community as sole decisionmakers Degrees of

7: Delegated power- community as chief decisionmakers Active involvement, Citizen

6: Partnership- community as co decisionmakers Power,

5: Placation-community as monitors Indirect involvement or

4: Consultation-community as respondents consultation, Degrees of

3: Informing-community as listeners

Tokenism

2:Therapy-community as users

Passive involvement or

1:Manipulation- community as pawn

manipulation, Non Participation

(Adapted from Arnstein (1967) and Shaffer (1994)

A key issue here is to explore how we can move from passive or indirect involvement of local people to active involvement in development activities, and thereby being able to merge Indigenous Knowledges with the "scientific knowledge”, termed Western Knowledge.

According to Breidlid (2013), Western Knowledge, has not been developed in a vacuum, "but its trajectory is inextricably linked to the spread of colonialism and capitalism and to the dislocation of other epistemologies” (p. 5). Similarly modernity has been associated with capitalism and westernization, in the sense that "progress has therefore also been linked to modernization, most often defined in opposition to tradition” (Tucker, 1999, p. 7). Westernization has therefore gained its status of a universal goal and destiny. The epistemological consequence, as may be seen today, is a tendency of creating a dichotomy between modernity and tradition, between indigenous knowledge and western knowledge. As 
stated by DuPlessis (2010), the traditional or established knowledge also carry the understanding of being universal. If we really want to be serious and implement the global UN objectives focusing on Education for Sustainable Development, this understanding has to be reversed. In the following section the concept, Education for Sustainable Development, will be further elaborated in order to frame Engeström`s theory of expansive learning in the context of sustainable development.

\section{Sustainable Development}

According to Breidlid (2013), sustainable development is almost entirely centered on a western and epistemological and ideological framework as discussed among the UN organizations. In the Johannesburg Declaration of Education for Sustainable Development the focus was on eradicating poverty and achieving a just and fair resource allocation. But education and training were referred to together with "Technology transfers, human recourse development, education and training to banish underdevelopment forever” (UN, 2002, p.18). Education was also noted as essential to mobilize natural resources as well as critical for promoting sustainable development. In The Declaration, it is also underlined the importance of the environment in sustainable development. This implies that Indigenous knowledge must be seen from this perspective. But Breidlid raise an important issue (2013, p. 70) when he asks; "How does the educational inputs promote sustainable development?"

Some of the answers to this is elaborated on by UNESCO (2005). In 2005,UNESCOlaunchedthe Decade of Education for Sustainable Development with the overall objective of integrating the principles, values and practices of sustainable development into all aspects of education and learning (UNESCO, 2005) as that effort will encourage changes in behavior that will create a more sustainable future in terms of environmental integrity, economic viability and a just society for present and future generations (UNESCO, 2005).Some writers questioned how the strategies could be both economically and environmentally friendly, others stated it was all just an attempt to show that capitalism is environmental friendly, again some argued that these two objectives were compatible (Breidlid, 2013, p. 71). Later UN documents, e.g. UNESCO/UNEP (2011, p. 48, as cited in Breidlid, 2013, p. 72) just sporadically mentioned indigenous knowledge, or the concept, local knowledge as in some instances is being used synonymously, as reflected in the following quote:

Indigenous and local knowledge is a key recourse for communities in understanding the environment, and assessing the adapting to climate change impacts....and Educational programs promoting indigenous knowledge, sustainable lifestyle and sustainable development will further enhance these capacities (critical thinking and problem solving skills. (UNESCO/UNEP, 2011, p. 48, as cited in Breidlid, 2013, p. 72)

These sporadic references to indigenous knowledge and the crucial role education could play to promote sustainable development by including local knowledge are the integral parts 
of an educational discourse promoting local and sustained developmental strategies. Along the following lines, I will use cultural-historical activity theory (CHAT) and the findings from two research projects to show a model that might bring new insights in how one can utilize and gain from merging different epistemologies, here indigenous and local knowledge and western knowledge systems.

\section{Applying the Model of Expansive Learning to Sustainable Development}

Expansive learning is based upon a sociocultural perspective drawing upon CHAT and reveals the connection between action and meaning among the relevant stakeholders in a given context or situation. Botha (2011) argues that partnerships between actors and institutions working towards a potentially shared development objective who historically have developed quite different and contradictory motives, tools and divisions of labor, e.g. indigenous and western, can be developed and analyzed using this theory as a model for sustainable development.

CHAT is characterized by work or activity-based learning. It relates to change at individual as well as institutional/organizational level, and focus on challenges and possibilities of inter-organizational learning. The process also requires a minimum of two interacting activity systems. CHAT also addresses cultural diversity by viewing possible conflicts among multiple systems, as essential for the development and learning, as contradictions, then will create new discussions, negotiations and provide openings for new perspectives and solutions.

The numerous meetings and/or workshops required for such a process to take place, have been named as Change Laboratory (CL) (Engeström, 2001). Such processes require the following: there is abroad stakeholder involvement, the roots of the problems are identified jointly, the stakeholders are collaborating and commonly envisioning future designs for change according to the given context and challenges, and thereafter joint agreed strategies which are partial and contingent (not absolute) are developed. Lastly a strategic work plan is approved ensuring a series of activities/workshops are taking place, for designing and redesigning possible strategies ahead.

\section{Empowerment and Reflective Practice}

The strategy also focuses on the empowerment of practitioners while engaging in reflective cycles of deconstruction, reconstruction, trial and re-adjustment. It is a participatory approach whose objective is to reveal the needs and possibilities for development in an activity, not in relation to a given standard or objective, but by jointly constructing the zone of proximal development of this activity.

The ideal-typical learning cycle termed expansive learning cycle (Engeström, 2001) is taking place in a multi-organizational context, and the step-wise learning cycle is illustrated below. The development process starts with questioning, challenging and rejecting existing practices across boundaries of existing organizations and institutions, across epistemological, 
ethnic or cultural boundaries. One starts analyzing existing practices in order to collaboratively and mutually contribute and support the building of new models, concepts, artifacts or patterns of conduct across previously identified boundaries. Thereafter, through reflections and examinations of the suggested models, concepts and artifacts, further negotiations and trading of material or immaterial resources related to new ideas, concepts and strategies are agreed. The expansive learning cycle will be finalized by reflecting on and evaluating aspects of the process and strategies by different stakeholders involved, before consolidating the outcomes and new practices, and if needed, revising the strategy based upon the experiences and outcome in the implementation of the first intervention, eventually starting the learning circle a second time.

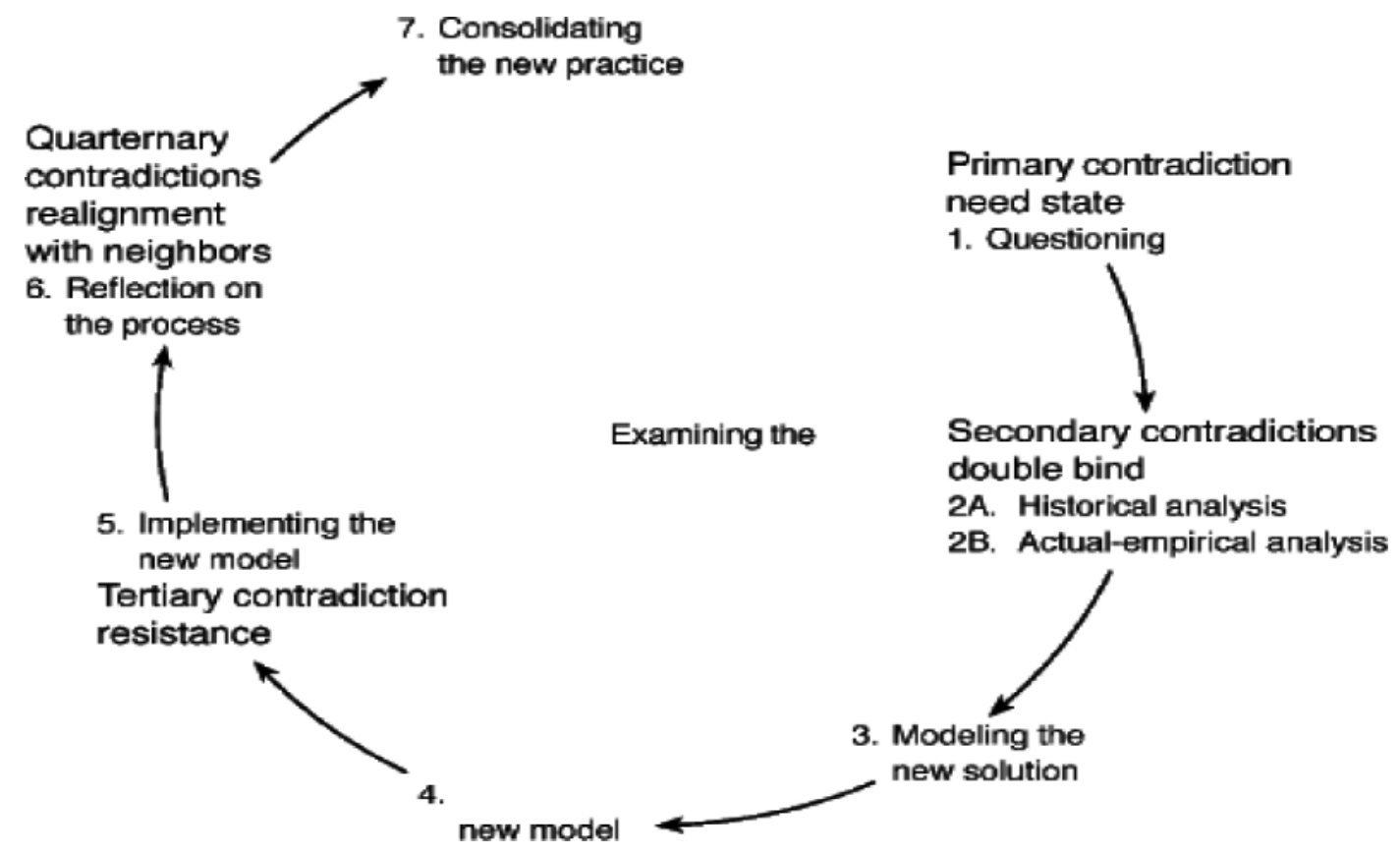

Figure 2. Expansive learning cycle (Engeström, 2001).

The five central principles of activity theory includes the following, a minimum of two activity systems as unit of analysis, a multivoicedness of activity, the historicity of activity, the contradictions as a driving force of change in activity, and the expansive cycles as a possible form of transformation in the activity. In conclusion, implications of this framework are the basic principles used for the understanding of the increasingly important horizontal dimension of learning being discussed.

\section{Creation of New Activity, Reflective Re-mediation}

Through reflective re-mediation one can open up an entirely new question and lead to the formation of a new object and a new activity. The limitation of goal-rational models of creation and change is that they require that the investigator or interventionist defines the desired outcome of the change effort at the beginning. Re-mediation involves a shift from the predefined or 'given new' goal to an unexpected or 'created new' object (Engeström, 1987). 
Imposed categories often become iron cages which reduce and rule out possibilities. Such closed 'stabilization knowledge' is commonly the result of exclusively authorized 'correct knowledge' (Engeström, 2001). Therefore, CHAT opens up an entirely new set of questions and leads to the formation of new objects and new activity.

\section{Boundary Crossing}

Applying a mixed methods approach through CHAT means using a theoretical framework that Westerners can relate to in order to delimit Western knowledge and research and thereby create an openly defined space for indigenous people to name and practice their knowledge(IKS), making procedures that state, where and how IKS would relate to Western knowledge (Botha, 2011). Boundary crossing actions are always two-way inter-actions. If only one party is willing to cross a boundary and receives no response, the action is incomplete and thus cannot be categorized as boundary crossing. To be expansive, such actions need to be characterized by mutual engagement and commitment to change in practices (Engeström, 2008).

Boundary crossing occurs because human beings are involved in multiple activities and have to move between them. For example, a school student must move from home to school to peer culture and back home where indigenous knowledge or traditional leadership is confronted with Western scientific knowledge or Eurocentric leadership practices (Breidlid, 2013). Boundary crossing provides material for double stimulation. It requires negotiation and re-orchestration. Therefore, it is the most obvious aspect of the horizontal or sideways dimension of development (Breidlid, 2013). Whether or not a boundary crossing action is expansive can ultimately and only be determined in the broader context of transformation in the activity systems and the participants involved. The model is further illustrated in the following diagram.

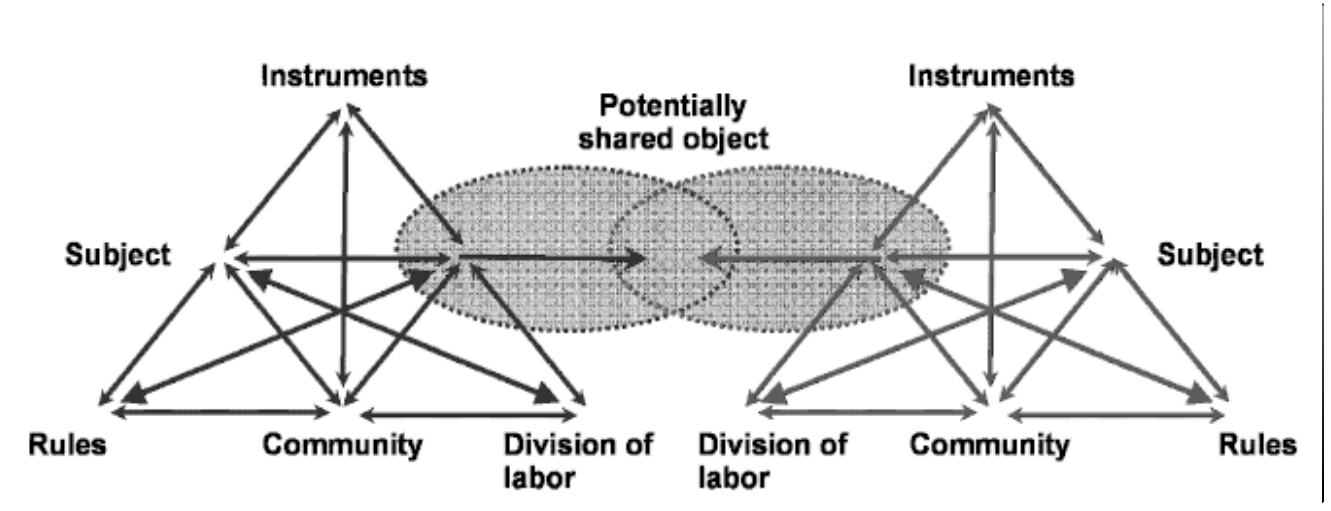

Figure 3. Two activity systems and a potentially shared object (Engeström, 2008, p. 4).

The upper part of the triangle represents individual and group actions embedded in an activity system- the instruments, the tools or the artifacts mediating learning and behavior. The lower part is referring to the division of labor between the actors involved in implementing the activity, targeting the given community. Finally the third corner or domain 
in the triangles reflects the existing rules that regulate the activity or action. The artifacts mediating peoples lived world are contextually bound, as are the divisions of labor and rules. For example, rules or artifacts guiding or controlling peoples lived world may in one context be based upon laws and jurisdiction, policies or institutional regulations, whereas in the other context, behavior may be rooted in cultural, spiritual or religious traditions and practices (Bernstein, 2010).

The oval representations are used to indicate the object-orientated actions whereby the two activity systems are interacting searching and negotiating to reach to a new innovative action, or a shared object of activity illustrated by the shared and overlapping part of the circles. That indicates how IKS and local knowledge can be merged through the facilitation of horizontal learning as "characterized by ambiguity, surprise, interpretation, sense making, and potential for change” (Engeström, 2001, p. 134). In the following section, I will illustrate some of the concepts of expansive learning to practical experiences and outcomes.

\section{Case Studies: Laos and Zambia.}

In the Lao study, the author was the team leader of an external UNESCO evaluation (2002), conducted jointly with the representative from the Laotian Ministry of Education, the UNESCO representative and one from NORAD. The overall aim of the project was to improve and sustain rural development (Carm, 2002). In Zambia, the author was hired by MOE Zambia as an external educational expert to support them in implementing the existing HIV/AIDS education policy in one province comprising a total of approximately 890 public schools. The team coordinating and facilitating the various activities were in addition to the author, MOE employees from different levels, as well as lecturers from one of the colleges in the province.

The two case studies referred to were directly focusing on the how and the why, trying to understand the strategies guiding the developmental processes, and the outcomes of the development projects, according to the voices of those directly involved. Both the studies employed an exploratory and qualitative case study approach based upon on a constructivist paradigm. These types of case studies are used to explore those situations in which the interventions being addressed have no clear, single set of outcomes (Yin, 2003, as cited in Bryman, 2008). A constructivist paradigm also acknowledges that truth is relative in the sense that it also depends upon the researcher`s perspective (Baxter \& Jack, 2008). "Constructivism is built upon the premise of a social construction of reality. One of the advantages of this approach is the close collaboration between the researcher and the participants while enabling participants to tell their stories” (Crabtree \& Miller, 1999, as cited in Baxter \& Jack2008). The unit of analyses in the Laotian case comprised three project districts, where 30 villages out of a total of 150 project sites were randomly selected. In the Zambian case, the unit of analyses was a province in which the decentralized approach to HIV/AIDS education was piloted over a period of four years. 
The findings revealed that the inclusion and thereby the role of the traditional leaders in fighting the HIV/AIDS epidemic through their own internal leadership structures and strategies were crucial in order for the MOE HIV/AIDS prevention strategy to be implemented (Carm, 2012). The table below clarifies the development objectives for each of the projects.

Table 3

Development Objectives for the Two Projects

\begin{tabular}{ll}
\hline Laos: Development objectives & Zambia: Development objectives \\
\hline -To improve the basic education level, & -To develop education strategies supporting \\
particularly for women and ethnic groups. & the Zambian government in fighting \\
-To contribute to sustained rural & HIV/AIDS at school and community level. \\
development in the central region of Laos. &
\end{tabular}

Both development projects were managed by a coordinating unit, which in both the cases also involved governmental representatives. But as can be seen in Table 3 below, there were a number of actors participating, some as planners, implementers, beneficiaries or both.

Table 4

Overview the Sample of Informants

\begin{tabular}{lll}
\hline Actors/Institutions & Laos & Zambia \\
\hline Govt. bodies & $\mathrm{X}$ & $\mathrm{x}$ \\
Higher ed./universities & $\mathrm{X}$ & $\mathrm{x}$ \\
International experts & $\mathrm{x}$ & $\mathrm{x}$ \\
National experts & $\mathrm{x}$ & $\mathrm{x}$ \\
Private inst./NGO & & $\mathrm{x}$ \\
Religious Inst. & & $\mathrm{X}$ \\
Local leaders & $\mathrm{X}$ & $\mathrm{X}$ \\
Community members & $\mathrm{X}$ & $\mathrm{X}$ \\
PTS/SMC & & $\mathrm{X}$ \\
Parents/households & $\mathrm{X}$ & $\mathrm{X}$ \\
Children, pupils & & $\mathrm{X}$ \\
\hline
\end{tabular}

In both the cases, a participatory approach was applied with the overall aim of reaching a working relationship that imply what Arnstein`s (1968) called Citizens Power opposed to manipulative strategies. A minimum of two activity-systems were involved as illustrated in Engeström`s model (2008). The meetings implied negotiations towards a new objective of Journal of Education and Research, March 2014, Vol. 4, No. 1 
activity, the needs, interests and environmental, as well as socio-cultural contextual conditions.

Responsibilities were delegated to the various institutional levels, e.g. household, community, local leader or chiefdom. Facilitation and support structured were in both cases developed and differentiated according to the needs.

Through questioning, analyses, interaction and horizontal learning, the various actors involved were sharing their ideas and thoughts reflecting their worldviews and epistemologies. Gradually the participants in each project modeled a local solution to improve or overcome their challenges and problems.

\section{Sustained Rural Development in Laos}

This project focused on improvement at the household and community-level targeting individual participants and beneficiaries of the project. A multi-channeled learning methodology was developed, where the beneficiaries identified and decided upon their learning needs, e.g. identified the themes and topics, which primarily were focusing on improving their livelihood through more efficient farming and the identification and implementation of new agricultural products suitable for their environment and climatic conditions. In close collaboration with the local and national experts, appropriate learning materials were designed, learning content and materials were developed and activities implemented through close monitoring and following up mechanisms. Village committees were representing the various beneficiaries, including the elders, and worked hand in hand with the project staff and coordinators.

The project was implemented in 150 villages, selected in 3 districts, and our impact research revealed a positive direct impact on health, nutrition, family planning, agriculture and livestock. Their improved living conditions and income generation activities indirectly impacted and changed traditional gender roles, and had a positive impact on increased enrolment among their children (Carm, 2002).

Some few examples will illustrate the impact, namely issues related to agriculture and livestock, one of the key areas for sustained rural development. They are also at the same time excellent illustrations of the term "boundary crossing” (Engeström, 2008).

By using new techniques such as the use of natural fertilizers they had increased their production of traditional crops. Moreover, new products had also been introduced to the villagers, e.g. cassava, watermelon, mushrooms and fish-farming through locally developed fishponds. With the introduction of livestock vaccines, especially for chicken and pig raising, they had increased the numbers and quality of their livestock. In addition, the village beneficiaries revealed that they did not only gain new knowledge and skills, but had also been encouraged to participate more fully in the decision-making processes in their communities (Carm, 2002). 
Scientific, Western, knowledge systems through the involvement of scientists and agricultural experts were merged with the beneficiaries' own situated wisdom, traditional knowledge and their own needs. The communities`need for improved living conditions and their voices were responded to by experts and project planners and facilitators. Through negotiations, considering environmental conditions and feasibility the two activity systems agreed upon a common strategy and the means and tools needed for the implementation in an illiterate environment where resources and infrastructural facilities were rare.

\section{Role of Traditional Leaders Promoting HIV/AIDS Prevention in Zambia}

In the Zambian case, the main aims were to pay attention to the role of the local leaders, the importance of bringing them fully into the planning and implementation process, and also their actual contribution using their own traditional management structures to identify risky behavior for contracting HIV/AIDS and develop mitigation strategies. Through their structures, their national chiefs` parliament, House of Chiefs, and their traditional governance of their "kingdoms" through head men and village structures, an otherwise taboo-related issue such as sexuality and HIV/AIDS were opened up to dialogue by their subjects through the chiefs` role as door opener to the villagers. Their new ways of working with the schools and teachers paved way for a coherent and comprehensive school-and community based approach fighting HIV/AIDS.

By looking at Figure 4 below, one can see how the three main groups of actors were involved, and the arrows illustrate the collaboration between the three main institutional actors, as well as how each of them also related to the individual stakeholders through their own administrational structures. Some of the innovations created by the traditional leaders and how that contributed to enlighten and create awareness in their kingdoms regarding HIV/AIDS are highlighted in the right column below.

Expansive Learning in-service model

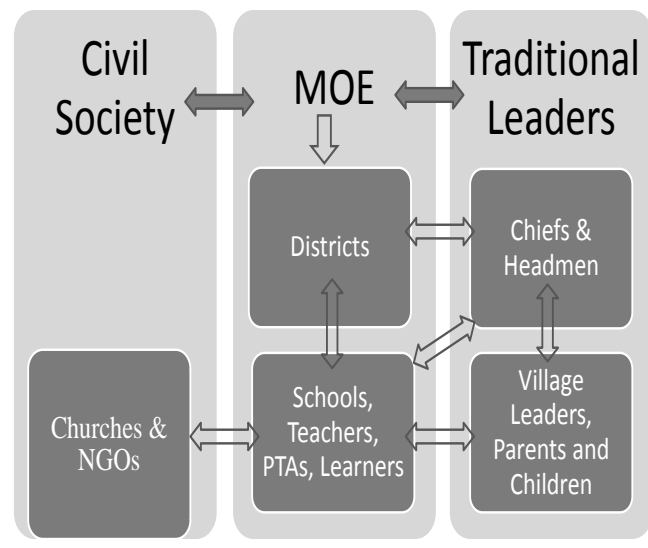

Figure 4. Interaction and coordination across activity systems.
- Monitoring HIV/AIDS education in the local schools

- Literacy classes including HIV/AIDS prevention were developed jointly with the schools/NGOs

- Chiefs use of media/TV to sensitize the public

- Increased openness about HIV/AIDS among the villagers though chiefs involvement and agency

- Reduction of stigma through greater openness between schools and parents/pupils related to harassment, misuse and HIV-infected pupils

- Sexual Cleansing were turned into other local rituals/and practices reflecting their 
local needs, herbal baths, back rubbing etc

- Chiefs were advocating for and changing the content of the initiation ceremonies, e.g. not promoting sexual intercourse and traditional gender roles during the ceremonies

- Polygamy was being discouraged.

These two case studies indicate how, by capitalizing on the positive dimensions of traditional knowledge and overcoming its negative dimensions through conventional science based inputs, difficult process of securing people's participation in environmental conservation together with the socio-economic development of local communities is eased. It also shows the important role local leaders can play as gate openers and agents for change, by bringing up crucial knowledge related to local traditions and cultural practices, and using their influence and their own rules and division of labor.

\section{Environment Education (EE) and Sustainable Development}

Sauve` (1996, p. 1) explored various conceptions of environment, of education and of sustainable development trying to identify what the concept of environmental education for sustainable development actually referred to. From his viewpoint, environment can be viewed as a pure nature, resource, problem, place to live, biosphere and community project. How do these definitions later impact how we then project the type of relationship and how we assign environment education to different principal characteristics? How does environmental education deal with the notions of the original, "pure" environment; our collective biophysical heritage, sustaining quality of life? Or does EE address how the environment is threatened by pollution, creating activists and change makers focusing on a shared living milieu; focusing on socially critical analysis or a political concern for the community?

Teaching and learning strategies that might be selected are then based upon our previous assumptions about the characteristics of the environment, e.g. nature exhibitions; immersion in nature, audit of energy consumption, problem-solving strategies, case studies or integral action research approaches through participatory process aimed at transformation.

A typology of environmental educational paradigms referred to by Sauve`(1996) shows the link between the typologies from A - C, and their corresponding educational paradigm, the typology's characteristics and lastly the applied pedagogical approaches. The first typology refers to the rational educational paradigm and has its origin in a traditional and vertical learning tradition, where education is understood as an information transfer process, mainly of a scientific, technological and legislative nature. 
Table 5

Sauve's (1996) Typologies of Environmental Education (EE) Paradigms

\begin{tabular}{|c|c|c|c|}
\hline $\begin{array}{l}\text { Environmental } \\
\text { Education } \\
\text { Paradigms }\end{array}$ & $\begin{array}{c}\text { Associated } \\
\text { Educational } \\
\text { Paradigm }\end{array}$ & $\begin{array}{c}\text { Principal } \\
\text { Characteristics }\end{array}$ & $\begin{array}{c}\text { Examples of EE } \\
\text { Pedagogical } \\
\text { Approaches }\end{array}$ \\
\hline $\begin{array}{l}\text { A } \\
\text { Industrial: nature } \\
\text { domination and } \\
\text { competition for } \\
\text { productivity and } \\
\text { growth }\end{array}$ & rational & $\begin{array}{l}\text { transmission of } \\
\text { predetermined } \\
\text { knowledge(mainly of a } \\
\text { scientific and } \\
\text { technological nature) }\end{array}$ & $\begin{array}{l}\text { formal } \\
\text { presentations or } \\
\text { demonstrations; } \\
\text { modules approach } \\
\text { for training }\end{array}$ \\
\hline $\begin{array}{l}\text { B } \\
\text { Existential: respect } \\
\text { for nature, in search for } \\
\text { harmony and personal } \\
\text { accomplishment }\end{array}$ & humanistic & $\begin{array}{l}\text { optimal } \\
\text { development of the } \\
\text { many } \\
\text { dimensions of the } \\
\text { learner; } \\
\text { "freedom to learn" }\end{array}$ & $\begin{array}{l}\text { Confluent approach for } \\
\text { nature education } \\
\text { or environmental } \\
\text { value education }\end{array}$ \\
\hline $\begin{array}{l}\text { C } \\
\text { Symbiosynergic: } \\
\text { toward symbiotic } \\
\text { relationship between } \\
\text { human, society and } \\
\text { nature }\end{array}$ & inventive & $\begin{array}{l}\text { Critical construction of } \\
\text { knowledge for social } \\
\text { transformation; } \\
\text { cooperative learning }\end{array}$ & $\begin{array}{l}\text { "grass roots" EE; } \\
\text { socially critical } \\
\text { environmental } \\
\text { education }\end{array}$ \\
\hline
\end{tabular}

(Adapted from Bertrand \&Valois, 1992, as cited in Sauve`1996, p.17)

The second and third paradigms though are corresponding to the situated or contextual understanding of knowledge, these last two typologies reflect a socio-cultural paradigm, focusing on the symbiotic relationship between humans, society and nature. The inventive (or transformative) paradigm favors critical construction of knowledge, implying the recognition of inter-subjectivity and transformation. This vision calls for new educational practices, such as making schools more open to the "real world," co-operative learning and concrete problem-solving. Many aspects of the socially critical environmental education correspond to this last vision (Sauve`, 1996).

\section{Sustainable Development and Environment Education}

Sustainable development as a concept can be understood as continuous development owing to technological innovation and free trade and/or development as dependent on a world order. The principal characteristics are productivity and competitiveness within a market-driven society with free trade on a world scale focusing on scientific and technological innovation or economic growth.

An alternative development credo argues that only a complete global shift in social values and choices will permit the development of sustainable communities and autonomous development, also called indigenous development. Linked to that, sustainable development, 
as can be argued, is valued if it is rooted in cultural identity. The principal characteristics of sustainable development are then further characterized by processes reducing dependency, increasing autonomy, favoring renewable resources, and stimulating democratic process, participation and solidarity. Associated educational strategies are reflected in the inventive paradigm and correspond to what we have previously called situated and contextual learning: a community-led process of critical investigation toward the transformation of social realities. Through interaction the relevant actors construct contextually significant and useful knowledge, taking into account traditional values and know-how (Sauve`1996, p.27).

The identification of relevant actors needs to be considered carefully, as well as how the various actors can contribute equally to the process of knowledge construction, to avoid manipulation and focus on active involvement (Arnstein, 1964). Keeping the inventive educational paradigm in mind, and focusing on environmental education and sustainable development, a corresponding method in this regard is reflected in the expansive learning theory of Engeström (2001, 2008), which illustrates how processes can be developed to ensure the merger of the various knowledge systems.

\section{Environment Education, Teaching and Learning}

Research shows that despite formal theory, in the end, it is the educator's personal theory, self-constructed whether explicit or not, that influences his or her daily pedagogical choices (Donnay \& Charlier, 1990, pp. 95-96; Hart, 1990, as cited in Sauve`, 1996). Therefore, before the design of any environmental education program or activity, it is important to clarify the underlying essential representations. Such a process should be encouraged within the framework of critical discussions concerning significant educational, environmental, social realities, local and global perspectives (Chambers, 2004, Freire, 1970).

Environmental education is by its nature an interdisciplinary project. Among a number of interrelated educational dimensions that might be included in environmental education, some of the following themes can be mentioned, peace education, human rights education, intercultural education, population education, international development education, and media education (Sauve`1996, p.17).Any responsible development must be defined contextually. Only when the activities are deliberately chosen by the community then it will guarantee a type of sustainability (Chambers, 2004, p. 29,). The main questions for sustainable development are the why? what? for whom? and how?

The goal of improving critical thinking is also fundamental to environmental educators' efforts to create an environmentally literate citizenry. In the face of complex environmental issues, environmental education does not advocate a particular solution or action, but instead facilitates a student's ability to draw on and synthesize knowledge and skills from a variety of subject areas to conduct inquiries, solve problems, and make decisions that lead to informed and responsible actions (UNESCO, 1978, as cited in Bright \&Tarrant, 2002). They further suggest that researchers can better measure the effectiveness of environmental education not 
by assessing environmental knowledge or perceptions regarding the truth about environmental information, but by examining their ability to think critically about complex issues. Thus, critical thinking and disposition toward critical thinking can be used as variables to evaluate environment-based education programs (Ernst \& Monroe, 2004, p.509).

Environment-based programs enhance students' critical thinking skills and disposition toward critical thinking when they integrate multiple disciplines using a common environmental theme, and involve open-ended projects that required hypothesizing, investigating issues and conducting research. These all are the aspects that empower students to be responsible for their own learning. By providing these opportunities for students, they will be able to react to what they have done or learned, and thereby helping them to make the connection to the real and local purpose of their efforts (Ernst \& Monroe, 2004).

\section{Concluding Remarks}

What are the conditions under which links of development, education and science are most likely to occur? The promise lies in cross-disciplinary, multi-disciplinary and cross sectorial approaches of policymaking, planning and implementation. We need to go beyond the rigid thinking along administrative division lines, social and scientific disciplinary subjects and narrow minded competition between disciplinary units (Takala, 2010, p. 7).

When raising the issue of how and if Environmental Education can contribute to sustainable socio-economic development, or whether science should be a good in itself, I would argue- we need to explore how environmental education, science and research can contribute to science for development and then having a development in mind that reflects a broad stakeholder contribution in deciding upon whose development and thereby also influencing how to resolve our challenges ahead.

There is also the question of whose social development? We have to look into the wider society to see how and where changes can be made which would support current efforts to promote sustainable change and improved livelihood of people. Sustainable development and change has proven to depend upon a local commitment and involvement. Experiences from Zambia and Laos show the importance of including participatory and inclusive methodologies, whereby one recognize the different worldviews and epistemologies as integral parts of environmental studies and development work. These approaches are able to enhance a critical and reflective consciousness, making the various actors aware of and conscious about their local heritage, environmental knowledge and how to include scientific knowledge as a potential and important contribution to sustained development.

\section{References}

Archer, D., \& Cottingham, S. (1996). Reflect mother manual. London, UK: ActionAid. Arnstein, S. (1967). Ladder of participation. Retrieved from http://www2.eastwestcenter.org /environment/CBFM/2_Arnstein.pdf 
Baxter, P., \& Jack, S. (2008). Qualitative case study methodology: Study design and implementation for novice researchers. The Qualitative Report, 13(4), 544-559. Retrieved from http://www.nova.edu/ssss/QR/QR13-4/baxter.pdf

Benjaminsen, T., \& Svarstad, H. (2010). Politisk Økologi, miljø, mennesker og makt [Politicalecology, environment, people and power]. Oslo, Norway: Universitetsforlaget [The University Press].

Bohta, L. (2011). Incorporating indigenous knowledge into our knowledge making: Experiences from a South African context (Unpublished doctoral thesis). Oslo University College, Oslo, Norway.

Breidlid, A. (2013). Education, indigenous knowledges and development in the global South: Contesting knowledges for a sustainable future. New York, NY: Routledge.

Bruns, B. (2003). Water tenure reform: Developing an extended ladder of participation. Paper presented at the RCSD Conference, July 11-14, Chiang Mai, Thailand. Retrieved fromhttp://www.usp.br/procam/govagua/Documentos/Biblioteca/governan\%C3\% A7a/bruns-ladder.pdf

Carm, E. (2002). Adult basic education and learning(ABEL) - An efficient tool for combating poverty? Lessons from Lao PDR. Paper presented at the NETREED Conference, 7-9 January, Oslo, Norway. Retrieved from http://www.netreed.uio.no/conferences/paper sconf.html

Carm, E. (2012). The role of local leaders in cultural transformation and development. Compare: A Journal of Comparative and International Education, 42(5), 795-816. doi:10.1080/03057925.2012.701484

Chambers, R. (1997). Whose reality counts? Putting the last first. London, England: Intermediate Technology Publications.

Chambers, R., \& Pettit, J. (2004). Shifting power to make a difference. In L. C. Groves \& R. B. Hinton (Eds.), Inclusive aid: Changing power and relationships in international development (pp. 137-162). London, UK and Sterling, VA: Earthscan.

Du-Plessis, J., \& Muzaffer, I. (2010). Professional learning communities in the teachers college: A resource for teacher educators. Washington, DC: USAID. Retrieved from http://www.equip123.net/docs/e1-PLCResource.pdf

Engeström, Y. (1987). Learning by expanding: An activity-theoretical approach to development research. Helsinki, Finland: Orienta-Konsulti.

Engeström, Y. (2001). Expansive learning at work: Toward an activity theoretical reconceptualization. Journal of Education and Work, 14(1), 133-156.

Engeström, Y. (2008). From teams to knots: Activity-theoretical studies of collaboration and learning at work. Cambridge, England: Cambridge University Press.

Ernst, J. A., \& Monroe, M. (2004). The effects of environment-based education on students' critical thinking skills and disposition toward critical thinking. Environmental Education Research, 10(4), 50-522.

Fortier, J. (1993). Nepalese indigenous labour relations. Contribution to Nepalese Studies, 20(1), 105-118. 
Hofstede, G. (1991). Cultures and organizations: Intercultural cooperation and its importance for survival. London, England: McGraw-Hill.

International Institute of Rural Reconstruction. (1996). Recording and using indigenous knowledge: A manual. Philippines: Author.

Organization for Economic Co-operation and Development. (2009). Aid effectiveness: A progress report on implementing the Paris declaration. Paris: Author.

Rao, K. S., Semwal, R. L., Maikhuri, R. K., Nautiyal, S., Sen, K. K., Singh, K., ... Saxena, K. G. (2003). Indigenous ecological knowledge, biodiversity and sustainable development in the central Himalayas. International Society for Tropical Ecology, 44(1), 93-111.

Rajib S., \& Anshu, S. (2007). Transferable indigenous knowledge (TIK): Progress and challenges. Retrieved from http://www.iedm.ges.kyoto-u.as.jp

Sauvé, L. (1996). Environmental education and sustainable development: A further appraisal. Canadian Journal of Environmental Education, 1, 7-33.

Shaffer, S. (1994). Participation for educational change: A synthesis of experience. Paris, France: International Institute for Educational Planning, UNESCO.

Sharma, U. (2004). Ecological restoration using indigenous knowledge in Nepal. Kathmandu, Nepal: Resource Development Initiative Center.

Sherpa, N. (2005). Indigenous peoples of Nepal and traditional knowledge. Paper presented at the International workshop on Traditional Knowledge, 21-23 September, Panama City, Panama.

Sillitoe, P. (1998).What, know natives? Local knowledge in development. Social Anthropology, 6(2), 203-220.

Takala, T. (2010).Contributions of formal education to social development - What do we know on the basis of research evidence. Journal of Education and Research, 2, 1-8.

Tritter, J. Q., \& McCallum, A. (2006). The snakes and ladders of user involvement: Moving beyond Arnstein. Health Policy, 76, 156-168. Retrieved from

http://www.engage.hscni.net/library/The\%20Snakes\%20and\%20Ladders\%20of\%20User \%20Involvement.pdf

Tucker, V. (1999). The myth of development: A critique of Eurocentic discourse. In R. Munck \& D. O. Hearn (Eds.), Critical development theory (pp. 1-26). London, England: Zed Books.

UNESCO. (2005). United Nations decade of education for sustainable development. Retrieved from http://unescodoc.org/images/0015/001587/158787e18012009

World Bank. (2005). Paris declaration on aid effectiveness: Ownership, harmonization, alignment, results and mutual accountability. Paris, France: Author. 